\title{
The issue of "false friends" in terms of learning a foreign language (Using the example of Georgian and English languages)
}

\begin{abstract}
As is generally known, "false friends" are words, which coincide formally or phonetically in the learner's native and target languages, but carry different (or partially different) meanings. Generally, the "false friends" phenomenon is studied in the context of translation theory and practice, as well as the language in the context of teaching linguistic or contrastive linguistics. Vocabulary is an important part of the learning process of a language. Teachers and learners face many obstacles regarding the learning of vocabulary during the learning and teaching process. One of the most important problems is exactly the issue of the so-called "false friends". Putting lexical units to the wrong use can lead to a learner's confusion or to a misinterpretation of the text. This issue is under-examined and unexplored in Georgian scientific literature and needs proper attention.

The aim of this paper is: 1. Identify such words on the basis of the data of Georgian and English languages and create the best possible basis for such words. These words are collected into relevant groups (complete distinction, partial distinction, parts of speech, etc.) and are presented in their relevant examples with analysis.

We have such lexical units in Georgian and in English:

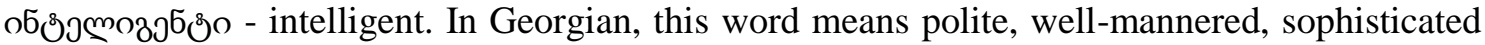
human, whereas in English it conveys a different meaning, clever.

мподобзмулю́ (peculiar, special) - original (present or existing from the beginning; first or earliest. created personally by a particular artist, writer, musician, etc.; not a copy).

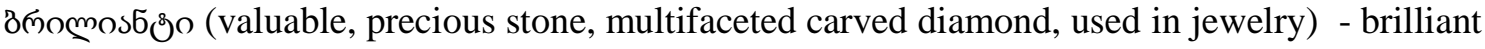
(exceptionally clever or talented. of light or colour, very bright.).

2. Another purpose of this article is to present activities that will help both the teacher and the student to overcome these difficulties. First of all, various lexical exercises, samples of which will be represented in the paper. 2. Vocabulary games 2. Translation. 4. Visualization. 5. Contextual and situational activities (using video and audio materials). 6. Corpus method aAccording to the data of both Georgian and English). 6. Tables and infographics.

The pilot lesson held for 5 students enabled us to identify the positive and negative aspects of the above-mentioned activities.

This paper has a practical value, and the results will be useful for language learners and teachers as well as translators in their field.
\end{abstract}

Key words: Phonrtics, false friends, SLE, vocanulary.

As is known in works dedicated to the issue, one of the most difficult problems to overcome when learning a language is that of "false friends". This phenomenon is frequently defined as "lexemes" on the verge of two (or more) foreign languages characterized by similarity regarding sound or graphical representation but a difference in meaning. These lexemes, coupled on the basis of the "lexical attraction" create a confusion in the process of translation and, most frequently, while teaching a foreign language (Abashidze: 2016, 34). It is believed that the basis of the existence of "false friends" is linguistic as well as cultural influences and these forms arise when two related languages come into contact. In addition, as it is argued in scholarly literature, 
the confusion created by "false friends" is not frequent in the case of two non-related languages as language learners do not particularly expect possible correlations between the two non-related languages. However, in the global world the spread of the "false friends" goes beyond the scopes of the related languages and continues creating problems for lexicographers and linguists. Scholars present different ideas about the phenomenon of "false friends" although the existence of cognates is also to be taken into consideration. Traditionally, cognates are defined as linguistic forms coming from one and the same historical source (Crystal 1997: 67) .At first sight, it can be argued that cognates must be based on related languages, but they can also be borrowed from other languages (Ialaits, Arginvaev, $2014: 60$ ). Cognates referred to as real friends can be defined as a pair of words which share both the sound form and meaning. Unlike these, "false friends" share the form but not the meaning in target languages. There are two types of "false friends" singled out: full and partial. In the first case, the shared forms reveal absolutely different meanings whereas the second case possess similar meanings as well as a different one. For instance, the word "concert" in Georgian denotes a musical performance which is also true for the English language. On the other hand, this word has one more meaning in English as seen from the following example: being in concert with somebody/something (being in cooperation with somebody/something ) (Ialaits, Arginvaev $2014: 61$ ). On the other hand, "false friends" are divided into three groups: (1) the first category is referred to as segregation. In this case pairs carry absolutely different meanings. (2) lexical pairs reveal both similar and different meanings; (3) this is referred to as inclusion when one member of the lexical pair reveals all the meanings of the other member as well as one more, "additional" meaning. (O'Neil, Casanovas $1997:$ 110).

In the process of the teaching/learning of a foreign language, the creation of "false friends" is encouraged by direct language or cultural transfer, which plays a negative role in this case. It can be argued that "the learners base their judgement on the meanings fixed in a shared cognitive base, largely, meanings known in their national discourse. This leads to inadequate and incorrect translation. (Gvarishvili 2011: 53).

\section{The significance of the issue}

In Georgian as in other languages which are closely connected with various languages and therefore, borrowings are not rare, the issue of employment of the "false friends" in the teaching and learning of a foreign language can be classed as one of the most important issues. Despite the fact that several separate works are dedicated to this problem in Georgian, they focus on the issue from the point of view of European languages taught to Georgian learners. However, lexical items making up the "false friends" have not yet been recorded and studied in Geogian.

"False friend" are inseparable parts of a lexical system of a language. Therefore, without proper understanding of their meanings, it is difficult to reach proficiency in a language. In addition, if learners of a second language do not know the exact meanings of such words, they may employ them incorrectly, which naturally becomes a hampering process of communication. It is well-known that when teaching a lexical item, it is not sufficient only to be aware of the exact semantics of a word and its equivalents in the native language. Knowing the meaning of the word includes the ability to use it in oral and written communication, knowledge of collocation models as well as that of syntactic, pragmatic and discursive models connected with it. This leads to active and productive as well as receptive knowledge (Carter, Maccartney 1991:43). This is the approach to rely on while teaching the "false friends. This study also discusses the issues regarding employment of false friends at the lexical (connotation), pragmatic and collocation levels.

The following aspects can be considered in reference to the above-mentioned:

\section{Connotations associated with lexical items}

The learners of the second language find it difficult to identify connotations of lexical items. In the case of the "false friends" the chances of making errors increase as the learner transfers the meaning based on their own languages (negative transfer) and frequently this may be the reason for the errors they make. For instance, 
in the following sentence: misma patetikurma sitkvam msmelei ver daainteresa. (The listeners were not interested in his pathetic speech). The word "pathetic" in English means "arousing pity, especially through vulnerability or sadness". However, in Georgian the word "patetikuri (pathetic) means high-flown and is negatively loaded. Therefore, this word falls in the risk group of potential errors. The same can be said about biurikratia (Bureaucracy). In Georgian this word is defined as a rule which is based on a bureaucratic formality (Georgian language explanatory dictionary). On the other hand, in English this word denotes 1) a) a body of non elective government officials; b) an administrative policy-making group. 2 government characterized by specialization of functions, adherence to fixed rules, and a hierarchy of authority. 3 a system of administration marked by officialism, red tape, and proliferation (https://www.merriam-webster.com/dictionary/bureaucracy). As can be seen, the word Bureaucracy in English denotes an administrative government and, unlike the Georgian word, it does not have negative connotation.

The same can be said about the word karieristi (careerist). In Georgian it refers to a person who is eager to be promoted and is characterized by a negative connotation. All 61 contexts of this word usage in the National Corpus of the Georgian Language bear a negative connotation. Therefore, the learners will realise that this word cannot be employed either in a neutral or positive sense unlike English in which careerist is defined as a person who follows a career. a person who pursues a policy or attitude of careerism. (http://www.dictionary.com/browse/careerist).

\section{Pragmatic usage of a word}

Although pragmatics is one of the principal domains regarding the teaching and learning of foreign languages it is not paid sufficient attention in classic textbooks. In this case, like previous ones, the "false friends" increase the chances of errors. Therefore, strategies of teaching the meaning of a word and its adequate use should be considered to be crucial. The student should be provided with extensive information about formality-informality of the register, the context and sphere of use in Georgian social space. From this point of view, it is advisable for intermediate and advanced students of Georgian to use the Georgian language corpus. For instance, the word preservative (condom) is not used in the meaning of condom in English, therefore, the students should realise the context and type of social interaction in which it can be safely used and feel when it should be replaced by the word " contraception".

\section{Collocations}

Let us analyse several examples. In Georgian the word "delikaturi" is defined as follows: 1. polite, tactful and considerate behavior. 2 demanding cautious and considerate treatment, a delicate question." (http://www.ena.ge/explanatory-online). Therefore, the collocations delikaturei peri (delicate colour) or delikaturi konstruktsia (delicate construction) are considered to be errors.

In English the word "gallant" has several meanings: (adjective) (of a person or their behaviour) brave; heroic; grand or impressive (of a man); charmingly attentive and chivalrous to women (Oxford Dictionary of English). On the other hand, in Georgian this word has only one meaning that of a polite and chivalrous man. Therefore, it was not unexpected that the learners of Georgian found the following collocations feasible:

- galanturi mtsdelob a (gallant attempt).

- galanturi dzalisxmeva (gallant effort).

- galanturi mogzauroba (gallant voyage) ${ }^{1}$.

These examples prove that the areas of potential errors are quite broad and demand attention from the teacher.

\footnotetext{
${ }^{1}$ Collocations are taken from English sentences http://sentencedict.com /gallant.html.
} 


\section{The goal of the research}

This study aims at identifying and describing the cases of "false friends" in Georgian and English. In addition, it explores the challenges the learners of the Georgian language face when tackling false friends. As well as this, practical recommendations are worked out for the teachers, which can be used while teaching Georgian as a foreign language to intermediate and advanced leaners. Specific exercises and activities are presented here to be used in the process of teaching Georgian. At the end of this article a small dictionary of "false friends" is given in which each Georgian item is provided with an incorrect and correct equivalents in English.

\section{Research methods}

The following research methods are used in order to achieve the goals of the research: experiment, personal observation by a teacher, analysis, and a method of corpus analysis.

\section{Constraints of the research}

The "false friends" are not classified according to the groups but are presented in alphabetical order.

\section{The experiment and its results:}

The experiment was carried out with 30 foreign learners of Georgian. The target group was divided into three subgroups. The first group comprised the students with the intermediate level of Georgian and English as a language of instruction. The native tongues of these students were German, Italian, English, Korean, Arabic and Persian. The members of the second group spoke Russian as their second language and Georgian at an intermediate level. The learners with the advanced knowledge of Georgian and English made up the third group.

The students were given the most frequently used 20 "false friends" both as separate lexical items and in sentences. The participants were asked to infer the meaning of the target lexical item. The sentences were as follows:

- Shemdeg ori simpatiuri akhalgazrda gamochnda (Then two simpaituri (most handsome) people appeared);

- kvellaze ekstravaganturi admianis tsodeba, am tsignis mixedviT, genialur mxatvar Salvador dalis mistses ( Salvador Dali, the genial painter was awarded the title of the most extravagant painter);

- es kitkhvebi dges ufor aktualuria ( These questions are more actual (important) today);

- finansuri investor da skepulianti milionebs aketebs (A finance investor and a speculator (the person who sells things at higher prices that bought) make millions;

- es batoni levanis kabineti iko (This was Mr. Levan's kabineti (study, office);

- asi dolari da ori didi brilianti hknda ( He/She had a hundred dollars and two big brilianti (diamonds);

- Giorgim blanki shavso (Giorgi filled in a blanki ( form);

- ramdenime pokusi gaaketa (He did several pokusi ( tricks);

- retseptis migeba fasiani momsaxureba ikneba (getting a retsepti ( prescription) is to be paid for);

- sachiroa tu ara parlamentis sxdonebis transliatsia (Is translation (broadcast) of Parliament sessions necessary?

- 18 tvis ganmavlobashi ori insulti hkonda. (He/She had two insulti (stroke) in 18 months.

Interestingly, the members of the first group were not able to understand or made mistakes while guessing the meaning of the target lexical items. However, the members of the second group scored $100 \%$ whereas the members of the third group showed $65 \%$ of correct answers.

It can be argued that the correct answers of the second group members which was partly true for the third group as well were determined by proficiency in Russian spoken either as a foreign language or as a native 
language. This is because these lexical items possessed similar meanings in Russian. On the other hand, as these words are not used in similar meanings in English, the students who spoke English were not able to guess the meanings correctly. This leads to the presupposition that the issue of "false friends" is a serious challenge for the learners of Georgian with English as their native or foreign language.

The next part of this article proposes the ways to overcome the discussed issue. In addition, it also offers instructions for teachers and practical tasks:

\section{Strategies to teach "false friends" and practical tasks}

\section{The strategies connected with understanding the meaning of the "false friends"}

As expected, this experiment suggested that the use of a word independent of a context leads to errors and therefore the teacher should present the lexical material in the context and work on it together with students. The following types of activities have proven to be effective:

1. Questions connected with the understanding of "false friends":

- Which of your familiar words does this word look like?

- Can the word in this context mean the same as in your language?

- What do you think this new word could mean according to the context?

2. Give the learner a context and 3 - 4 suggested answers and put a question::

- What do you think this new word could mean according to the context?

\section{For instance:}

akhal sakhlshi mas sakutari komfortuli hkonda, sadac daistera misi literaturuli shedevri.

(In his new house he had a comfortable "kabineti", in which his literary masterpieces were written). The question: what could the word "kabineti" mean?

1) a room 2) a cabin 3) a cupboard 4) a working room

3. Give students a definition of the word in the target language (from the dictionary or, if necessary, compiled by the teacher) (Pcholinska, 2010). We believe that best results are achieved when students look up such lexical items themselves.

4. Translation. Ask students to look for the translation of the word independently. Interfere only as absolutely necessary.

5. Offering a broad context. Ask students to infer the meaning of the "false friends" based on the broad context, several sentences or a paragraph.

6. Introducing synonymous items. Students are introduced to familiar synonyms of the target lexical items. This helps them to guess the meaning successfully.

7. Use of antonyms. While learning "false friends" it is also effective to use their antonyms. (Mote http://litu.tu.ac.th/FLLT2013/www. fllt2013.org/private_folder/Proceeding/377.pdf).

8. The teacher asks students to make up a Georgian-English dictionary of "false friends", to which new items can be added.

9. Matching exercises facilitates memorizing words as well as revision of the material.

\section{For instance:}

- Match the following Georgian and English words:

$\begin{array}{ll}\text { pokusi } & \text { grade } \\ \text { kompositori } & \text { trick } \\ \text { klasi } & \text { music writer }\end{array}$

- Matching the following words and their definitions: 


\begin{tabular}{|l|l|}
\hline Kabineti ( a study) & Precious stone \\
\hline Pokusi ( a trick) & A room in the house used for studying or mental work \\
\hline Brilianti (diamond) & A skillful act performed for entertainment or amusement. \\
\hline
\end{tabular}

- Match the word and the text logically/find a logical connection between the word and the text

\begin{tabular}{|l|l|}
\hline Prospekti ( avenue) & $\begin{array}{l}\text { Mr. David was admired by women even when he was old. He always } \\
\text { looked well. When meeting a lady she knew, he always greeted her by } \\
\text { taking off his hat and kissing her on the hand }\end{array}$ \\
\hline Galanturi ( gallant) & $\begin{array}{l}\text { Beautiful open cafes opened in a straight and wide street. Soon this } \\
\text { street became a favourite place for locals and tourists. }\end{array}$ \\
\hline
\end{tabular}

9. In order to solve such lexical problems True/False exercises are very effective

\section{For instance:}

An efficient woman is referred to as "accurate"

True $\quad$ False

"Tomati" is a tomato sauce

10. Use of visual materials.

As is well-known, visualization facilitates the process of learning and memorizing. At the same time, this activity also helps the student memorise and categorise the words. Students are shown 2 photos one of which contains the words in their native language whereas the other - the words in the target language.

\section{For instance:}

A man wearing "smokingi" (tuxedo) and "a smoking man"

Next students are asked to write the words they had just learnt on the blackboard (each student writes only one word) while others put up a corresponding photo under it.

\section{Mind maps}

Students are asked to place the target word in the middle of the map and map all the familiar words phonetically or semantically connected with the target word. At the next stage the teacher and the students continue working on mind maps.

- Students group phonetically similar words and comment on semantic similarities and differences between them.

- Students identify and group semantically similar but phonetically different words.

- Students identify and group synonyms and antonyms.

- Students identify and group parts of speech.

13. Word networking:

- Students copy the definition of the word from the target language dictionary and the translation dictionary.

- At the next stage, when the meaning of the "false friends" is already known to them, students write words associated with the central target word.

- In order to enrich their associations, students address syntagmatic (linear) and paradigmatic (based on associations) methods (Gass, Selinker 2006 : 457 - 458 


\section{For instance}

\begin{tabular}{|c|c|c|c|}
\hline \multicolumn{2}{|c|}{ Syntagmatic: } & \multicolumn{2}{|c|}{ Paradigmatic } \\
\hline $\begin{array}{l}\text { Word } \\
\text { himni }\end{array}$ & $\begin{array}{l}\text { answer } \\
\text { simgera (song) } \\
\text { kvekana(country) }\end{array}$ & $\begin{array}{l}\text { word } \\
\text { himni }\end{array}$ & $\begin{array}{l}\text { answer } \\
\text { siamake (pride) } \\
\text { emotsia (emotion) } \\
\text { gulze midebuli kheli (a hand on the } \\
\text { heart) }\end{array}$ \\
\hline
\end{tabular}

- Students wite synonyms and antonyms.

- Finally, students find 2 - 3 sentences with new "false friends" in the National Corpus of the Georgian Language

It is recommended to practice this type of work with students who speak Georgian at intermediate or upper intermediate levels. At the next stage students share one another's work and identify similarities and differences between them. (This is memorizing lexical items through repeating). Students identify errors and assess them.

\section{Conclusions}

The learning of the second language is a difficult process influenced by a number of linguistic (the first language, the language of instruction, general pre-linguistic knowledge...) and extra-linguistic (environment, motivation, general intelligence level, time...) factors.

The experiment revealed that the learners of the Georgian language, like learners of any other language perceive the "false friends" through their own language (negative interference). In order to overcome this challenge, at the first stage it is advisable to teach the meaning of a "false friend" through a guided discovery (a dictionary, broad context, visualization) and not by mechanical memorization. Activities which facilitate broadening and enhancing the knowledge are introduced only after this. As well as this, well-known activities (mind maps, words networking) are introduced as learning resources, which is one of the novelties of this work. It should also be mentioned here that the "false friends" are well-known and spread in Georgian. According to the National Corpus of the Georgian language, the most widely spread "false friend" is the word "generaluri" which appears in the corpus 47750 times. Another widely spread word is "originaluri"- which appears 3989 times as well as aktualuri, regularuli, sistematuri, efekturi. These data emphasize the significance of the meaning of lexical items and knowledge of the strategies of their use to build up effective communication. Finally, the knowledge of the "false friends" and their adequate use enhances the discursive and sociocultural competences of the learner.

In the final part of the article a Georgian-English dictionary of "false friends" is presented which is one of the novelties of this study. Each of the Georgian lexical items is accompanied by an incorrect meaning and an adequate word in English. Practical recommendations and the dictionary will, by all means, help the teachers and learners as well as people interested in this issue.

\begin{tabular}{|l|l|}
\hline aborti - Abort - Abortion & inteligenti -Intelligent - Cultured \\
akordi - Accord - Chord & imparkti- imparkt - Heart Attack \\
akuratuli - Accurate - Orderly, clean. & intsidenti - Incident - Unpleasant event, Quarrel; \\
artisti - Artist - Actor/actress & conflict \\
akadenimosi - Academic - Academician & kabinet - Cabinet -Office, study-room \\
\hline
\end{tabular}




\begin{tabular}{|c|c|}
\hline $\begin{array}{l}\text { designer } \\
\text { dekoratsia - L }\end{array}$ & $\begin{array}{l}\text { Condom, contracept } \\
\text { tic } \\
\text { rsal } \\
\text { k, retort } \\
\text { rescription }\end{array}$ \\
\hline
\end{tabular}




\begin{tabular}{|c|c|}
\hline $\begin{array}{l}\text { window. } \\
\text { indeqsi - Index - Zip code } \\
\text { insulti- Insult - Stroke } \\
\text { instrumenti - Instrument - Tool }\end{array}$ & $\begin{array}{l}\text { smokingi - Smoking - Tuxedo } \\
\text { spekulianti - Speculator - Dealer, Illegal seller } \\
\text { taloni - Talon - Coupon } \\
\text { tomati - Tomato - Tomato paste } \\
\text { tramvai - Tramway - Tram } \\
\text { tramplini- Trampoline - Springboard, ski jump } \\
\text { translatsia - Translation - Broadcast } \\
\text { transparanti- Transparent - Banner } \\
\text { trapezi - Trapeze - Repast } \\
\text { umaglesi skola - High school - University } \\
\text { himni - Hymn - Anthem } \\
\text { pabrika - Fabric - Factory, Plant } \\
\text { pokusi - Focus - Magic, Trick. } \\
\text { shepi- Chef - Boss, patron. }\end{array}$ \\
\hline
\end{tabular}

\section{References}

Abashidze, N., "False Friends of the Translator" as a Didactic Problem and its Lexicographic Aspect (On the Material of French and Georgian Languages), Batumi II International Symposium in Lexicography, Proceedings(http://www.ice.ge/new/batumi/Batumi 2012.pdf

Carter, R., McCarthy, M., Vocabulary and Language Teaching, London, Longman, 1991

Crystal, David, Dictionary of Linguistics and Phonetics (IV edition).Oxford, Blackwell 1997.

Gass Susan M., Selinker, Larry, Second Language Acquisition. Third edition. 2006

Gvarishvili, Z. Translator's "false friends" problem in the Process of Second Language Teaching, Issues of State Language Teaching, Problems and Challenges, Conference Abstracts, Tbilisi, 2011

Mothe, Prashant Subhash, Innovative Techniques of Teaching Vocabulary at the Intermediate Level in the Second Language Classroom, http://litu.tu.ac.th/FLLT2013/www.fllt2013.org/private_folder /Proceeding/377.pdf, retrieved at 31th of January, 2018

O'Neill, M., Casanovas, M., False friends: a historical perspective and present implications for lexical acquisition, http://www.raco.cat/index.php/Bells/article/view/102791/149196

Pčolinská, A., How to Present Vocabulary in a Language Classroom in a Communicative Way, 2010, in February, Humanizing Language Teaching, http://www.hltmag.co.uk/feb10/sart03.htm, retrieved at 31th of January, 2018

Rufus, H., Gouws, D. J. Prinsloo,, Gilles-Maurice de Schryver ${ }^{\circ}$, 2004, Friends will be Friends - True or False. Lexicographic Approaches to the Treatment of False Friends, 2004.

\section{Sources:}

Explanatory dictionary of the Georgian language - http://www.ena.ge/explanatory-online Merriam Webster Dictionary online https://www.merriam-webster.com/dictionary/bureaucracy Oxford Dictionary of English - (https://en.oxforddictionaries.com/definition/gallant) National Corpus of the Georgian Language http://clarino.uib.no/gnc/page?page-id=gnc-main-page 